\title{
Композиционная роль видо-временных категорий в стихотворении Б. Пастернака «Чудо»
}

\author{
Józefina Piątkowska (Varšava)
}

\begin{abstract}
Аннотация
В нашей работе мы хотим показать, как для анализа лирического стихотворения можно применить методологию исследования нарративных текстов с точки зрения зависимости салиентности от аранжировки видо-временных категорий. Предметом нашего рассмотрения станет стихотворение Б. Пастернака Чудо, помещенное автором в сборник Стихотворения Юрия Живаго. В структуре Чуда можно выделить две части: повествовательную, в которой описывается история испепеления Иисусом Христом смоковничного дерева, и философскую, содержащую рефлексию лирического «я» над этим сюжетом. Особое внимание мы уделим тому, каким образом видо-временные категории могут выполнять композиционную функцию, обеспечивая выдвижение на первый план лирического высказывания его важнейшей информации.
\end{abstract}

\section{Ключевые слова}

салиентность; первый план и фон; время и вид глагола; лирическое стихотворение; Борис Пастернак

\section{Abstract \\ Discourse Functions of Tense/Aspect Morphology in Lyric Poetry - the Case of Miracle by Boris Pasternak}

Over the last decades serious research has been done on the correlation between tense and aspect choice and the level of information saliency in narrative discourse (Chvany 1985, 1990, Ehrlich 1987, Fleischman 1990, Givon 1987, Hopper and Thomspon 1980). The aim of this article is to demonstrate how methods used to analyse foreground/ backround distinction in narrative texts could be applied in order to investigate lyric poetry. The poem I shall examine is Miracle by Boris Pasternak, which belongs to a cycle of twenty-five poems, entitled Poems by lurij Zhivago. The poem falls into two parts: the first one is narrative and relates the episode of the barren fig-tree, the second part is strictly philosophical and reflects on the force which overcomes the ordinary causality of events. My main concern is to reveal what role tense-aspect morphology plays for the foregrounding of the main ideas of the lyrical "l".

\section{Key words}

foreground/background; saliency; tense and aspect; lyric poetry; Boris Pasternak 


\section{Введение}

В нашей работе мы хотим показать, как для анализа лирического стихотворения могут быть применены достижения так называемой «теории многоплановости дискурса» (англ. theory of grounding), в рамках которой были до сих пор последовательно и масштабно исследованы нарративные тексты. Предметом нашего рассмотрения станет стихотворение Б. Пастернака Чудо, помещенное автором в сборник Стихотворения Юрия Живаго. Оно открывает внутренний цикл произведений, посвященных размышлениям пастернаковского героя о евангельских событиях Страстной недели. В структуре Чуда можно выделить две части: повествовательную, в которой описывается история испепеления Иисусом Христом смоковничного дерева, и философскую, содержащую рефлексию лирического «я» над этим сюжетом. Особое внимание мы уделим тому, каким образом видо-временные категории могут выполнять композиционную функцию, обеспечивая выдвижение на первый план лирического высказывания его важнейшей информации. В первой части нашей работы мы коротко отреферируем важнейшие положения концепции многоплановости дискурса (англ. foreground/background), касающиеся как нарратива, так и лирики, и укажем, в каких моментах принятые в обоих случаях подходы согласуются друг с другом. Во второй части мы предложим анализ стихотворения Чудо.

\section{1. Многоплановость дискурса: основные сведения}

Стремление разделять более и менее важную информацию (стремление к перспективизации) характерно практически для любой деятельности человека. При визуальном восприятии - смотрим ли мы, например, на картину или спектакль - одни объекты привлекают к себе особое внимание, а другие уходят на задний план. Подобное правило проецируется также на информационную структуру языка. Как отмечает Г. Зельдович: «Известно, ито значение и отдельного слова, и целого предложения как правило устроено “многослойно». Значение слова слагается в общем случае из ассерчии, пресуппозиций, модальной рамки и иных не одинаковых по природе и неодинаково ранжированных смыслов. Значение предложения (если, конечно, говорить о его прямом, не обогащенном разного рода инферениией, прагматическим «выводом» смысле) слагается из темь и ремь, причем тема-рематическая структура у сколько-нибудъ развернутого предложения как правило многоступенчата $[\ldots] »^{1}$.

Дискурсу также свойственна подобная многослойность. «Понимание дискурса как структурированной иелостности требует разграничения более и менее примечательнъх его составляюших. Без этого экспрессия была бы невозможной. Дискурс без выделенных

1 ZEL'DOVIČ, G. M.: Diskursivnye otnošenija v liričeskoj poèzii. Suggestivnaja funkcija. 2017 (рукопись). 
компонентов воспринимался бы так, будто кто-то указывает на черную табличу и настаивает, что это образ черньх верблюдов, которые идут ночью по черному песку»².

\section{1 Первый план и фон в нарративе}

В прототипических нарративных текстах обычно выделяются первый и второй планы (англ. foreground и background; см. работы известных лингвистов: П. Хоппера "Aspect and foregrounding in dicourse»", П. Хоппера и С. Томпсон «Transitivity in grammar and discourse $»^{4}, \mathrm{X}$. Драй «The movement of narrative time $»^{5}$, К. Чвани «Background perfectives and plot-line imperfectives: towards a Theory of Grounding in text»" ${ }^{6}$ С. Эрлих "Point of View. A Linguistic Analysis of Literary Style» ${ }^{7}$, С. Флейшман «Tense and Narrativity: from Medieval Performance to Modern Fiction ${ }^{8}$, Т. Гивона «Beyond foreground and background $»^{9}$, Л. Джонс и Л. Джонса "Multiple levels of information relevance in discourse» ${ }^{10}$ и Р. С. Томлина "Foreground-background information and the syntax of subordination $\left.{ }^{11}\right)$. В самом общем смысле, как объясняют П. Хоппер и С. Томпсон, «та часть дискурса, которая не относится непосредственно к иели говорящего, но лишь расширяет, комментирует, поясняет ее, называется фоном. В противоположность этому, материал, обеспечивающий выражение основного содержания текста, называется первым планом» ${ }^{12}$. Как это выразил полвека тому назад В. Хейнрих, “речъ здесъ идет о том, ради чего рассказывается данная история, и о том, ито просто помогает читателю ориентироваться в мире рассказа» ${ }^{13}$.

Исследователи нарратива, принимая за главную цель повествования в каждый его отдельный момент ответ на вопрос А ито случилось потом?, указывали, что та часть нарратива, где содержатся такие ответы, составляет его главный каркас,

2 LONGACRE, Robert E.: The Grammar of Discourse. New York: Plenum, 1985, s. 83. FLEISCHMAN, Suzanne: Tense... Op. cit., p. 184.

3 HOPPER, P.: Aspect and foregrounding in discourse. In: GIVON, Talmy (ed.): Syntax and semantics, Discourse and syntax, vol. 12, New York: Academic Press, 1979, pp. 213-241.

4 HOPPER, Paul-THOMPSON, Sandra: Transitivity in Grammar and Discourse. Language 56, 1980, pp. 251-299.

5 DRY, Helen: The movement of narrative time. Journal of Literary Semantics 12, 1983, pp. 19-53.

6 CHVANY, Catherine: Backgrounded Perfectives and Plot-Line Imperfectives: Towards a Theory of Grounding in Text. In: FLIER, M. S. - TIMBERLAKE, A. (eds.): The Scope of Slavic Aspect. Columbus, Ohio: Slavica, 1985, pp. 247-73.

7 EHRLICH, Susan: Point of View. A Linguistic Analysis of Literary Style. London: Routledge Revivals, 1990.

8 FLEISCHMAN, Suzanne: Tense and Narrativity: from Medieval Performance to Modern Fiction. Austin: University of Texas Press, 1990.

9 GIVÓN, Talmy: Beyond Foreground and Background. In: TOMLIN, Russell S. (ed.): Coherence and Grounding in Discourse, Amsterdam: Benjamins, pp. 175-88.

10 JONES, Lary - JONES, Linda: Multiple levels of information relevance in discourse. Discourse Studies in Mesoamerican Languages, 1: Discussion: JONES, Linda (ed.). Dallas TX: SIL and University of Texas at Arlington, 1979, pp. 3-23.

11 TOMLIN, Russell S.: Foreground-Background Information and the Syntax of Subordination. Text 5, 1985 , pp. 85-122.

12 HOPPER, Paul - THOMPSON, Sandra: Transitivity... Op. cit., p. 280.

13 WEINRICH, Harald: Tempus. Besprochene und erzählte Welt. Stuttgart: Kohlhammer, 1971, p. 94. 
а все остальное - это вспомогательный материал. Иначе говоря, в повествовательном тексте отчетливо разграничиваются «первоплановая» линия событий и «второплановые» описания обстоятельств и героев, т.е. так называемый фон.

В языках мира можно обнаружить набор многообразных средств, которые маркируют в повествовательном тексте его первый план и фон. Одним из важнейших маркеров является видо-временная форма глагола. В упоминавшейся уже нами статье Хоппера и Томпсон отмечалось, что в языках, в которых выделяется перфектный и имперфектный вид глагола, формы перфектного вида (динамические, пунктивные и завершенные) обычно маркируют первый план, оформляя основную линию событий, а глаголы имперфектные (описывающие состояния и длительные ситуации) участвуют в выражении комментариев и прочей дополнительной информации. Тем самым категории времени и вида (аспекта) выполняют дискурсивную, а не только чисто референтную функцию, состоящую в выражении локализованности ситуации на временной оси (время) и характера ее протекания во времени (вид).

Хоппер и Томпсон исследовали, однако, самые простые, устные нарративные истории. Их последователи (например, К. Чвани С. Флейшман, С. Эрлих), которые анализировали более сложные, художественные тексты, доказали, что отождествление «первый план = самая значимая информация = событийная линия текста» и «фон = второстепенная информация = комментарии» не всегда актуально. К таким исследованиям принадлежат работы К. Чвани которая анализировала произведения Л. Толстого и А. Чехова. В ее разборах показано, что различные художественные эффекты могут быть достигнуты в русском языке посредством «перфективов фона» (англ. backgrounded perfectives) и «имперфективов линии событий» (англ. plotline imperfectives). Приведем самый наглядный и чаще всего приводимый пример ${ }^{14}$ из чеховского рассказа Cnamъ хочется: «Смеясь, подмигивая и грозя зеленому пятну пальиами, Варька подкрадывается к колыбели и наклоняется к ребенку. Задушив его, она бъстро ложится на пол, смеется от радости, ито ей можно спать, и через минуту спит уже крепко, как мертвая...». ${ }^{15}$

Согласно К. Чвани при помощи деепричастия задушив самое человечески значимое и страшное событие отведено Чеховым на задний план (в фон). На передний план Чехов выносит названные несовершенным видом глагола действия главного персонажа, сосредотачивая внимание читателя на состоянии измученной бессонницей девушки, для которой возможность поспать становится важнее совершенного преступления.

14 Этот же пример использует в своей работе Е. Шен (SHEN, Yeshayahu: Two levels offoregrounding in literary narratives. In: ZYNGIER, S. - BORTOLUSSI, M. - CHESNOKOVA, A. - AURACHER, J. (eds.): Directions in Empirical Literary Studies: In honor of Willie van Peer. Amsterdam - Philadelphia: John Benjamins Publishing, 2008, pp. 103-111, 146); заметки о художественном времени в «Спать хочется» Чехова находим также в статье Д. С. Лихачева (LIHAČEV, D. S.: Poètika hudožestvennogo vremeni. Poètika hudožestvennogo prostranstva. In: LIHAČEV, D. S.: Poètika drevnerusskoj literatury. Moskva: Nauka, 1979, s. 209-351.).

15 ČECHOV, A. P.: Spat'hočetsja. [электронный ресурс] https://ilibrary.ru/text/683/p.1/index.html (дата доступа 13.09.2018.) 
Вид и время - это, конечно, весомые, но отнюдь не единственные грамматические и дискурсивные средства обсуждаемого здесь ранжирования. Фокусировать и дефокусировать внимание читателя можно, используя также порядок слов, тип клауз (подчиненный / неподчиненный), прямую речь и др. Как отмечает С. Флейшман, «маркирование переднего плана и фона в языке предполагает взаимодействие разных признаков, которые могут либо поддерживать друг друга, либо нет ${ }^{16}$. Для нас главное, что выбор времени и вида служит не только указанию локализации ситуаций на временной оси, но также проявлению намерений автора выдвинуть некоторые элементы на передний план или - наоборот - поместить их в фоне и отвлечь от них внимание читателя.

\section{2 Эмпирическая и обобщающая части лирического стихотворения в модели, предложенной Тамарой Сильман}

Применяемое к нарративу различение первого плана и фона актуально и для лирики. Вслед за Т. Сильман ${ }^{17}$, в структуре лирического текста также можно выделить две части: центральную обобщающую и вспомогательную эмпирическую. ${ }^{18}$ В лирике на передний план выдвигается обобщение, т.е. итог или, иначе говоря, момент постижения лирическим героем какой-то истины. Именно этот момент является стимулом, движущим стихотворение, а все «эмпирическое»описание любого опыта или фактов - создает соответствующий фон. Любые действия лирического героя, поведение природы и т.п. - все это появляется в лирическом тексте, только «если оно важно для точки зрения лирического героя и находится в непосредственной связи с сюжетом данного стихотворения»19. Эмпирические подробности обеспечивают «минимум коммуникативности», чтобы миг постижения хотя бы в какой-то степени стал доступным пониманию читателя.

Эти две главные части лирического стихотворения - эмпирическая и обобщающая - могут быть «неравны по своему размеру и значению, ибо чаще всего первая, эмпирическая часть обвемнее, в то время как вторая, обобщаюшая, приниипиально значительнее, но короче» ${ }^{20}$.

Как отмечает Сильман, «вся эта сравнительно большая программа стремится к осуществлению в самых жестких рамках минимума текстового пространства, в величайшей тесноте и „скученности” (вспомним формулу Тынянова: „теснота стихотворного

16 FLEISCHMAN, Suzanne: Tense... Op. cit., p. 184.

17 SIL'MAN, T. Ja.: Zametki o lirike. Leningrad: Sovetskij pisatel', 1977.

18 Как указывает сама Т. Сильман: «выдвигаемая нами здесь модель не универсальна, не покрывает всего многообразия конкретных типов смыслового построения лирических стихотворений. Но всеже она представляется нам исключительно важной, как бы ключевой формой, установление которой может помочь и лучшему пониманию других структур лирического стихотворения - в их сходстве и в их различии». Ibidem, s. 5.

19 Ibidem, s. 6.

20 Ibidem, s. 7. 
ряда")» ${ }^{21}$. В качестве примера Сильман приводит стихотворение итальянского поэта Джузеппе Унгаретти:

И я люблю тебя, люблю тебя, и это нескончаемое страдание!...

Даже в стихотворении, содержащем лишь одну строку, можно выделить эмпирическую и обобщающую части. В первой из них говорится о факте любви, а во второй это чувство квалифицируется как страдание.

Привлекательно отождествить в лирике обобщение с первым планом, а эмпирическую часть с фоном, наподобие того, как в прототипическом нарративе с первым планом принято отождествлять событийную линию, а с фоном - комментарии и вспомагательный материал. Однако не стоит забывать, что не каждому типу поэтических произведений присуща структура, отражающая переход от внешнего, эмпирического плана к плану внутренних переживаний. Например, в некоторых стихотворениях $\Phi$. И. Тютчева «философская мысль выражена непосредственно, а конкретный жизненный материал как бы «всасывается» в обобщение в плане метафорическом. Иначе говоря, между основной точкой отсчета и конкретным материалом действительности уже нет никакой дистаниии». ${ }^{22}$

Как в нарративе, так и в лирическом стихотворении граница между первым планом и фоном может, но необязательно должна являться жесткой. В упомянутых нами работах доказывается, что уровень значимости (т.е. салиентность) информации - это скорее вопрос градуальности, чем дихотомии. Салиентность может маркироваться при помощи разных языковых средств, и их набор определяет дискурсивное место соответствующей единицы - оно может быть ближе либо к первому плану, либо к фону. Иначе говоря, не все элементы первого плана одинаково значимы. При этом выдвигаться на первый план могут также и некоторые компоненты фона.

В лирике - для которой жанровым, естественным требованием является лаконичность высказывания - на небольшом пространстве могут максимально концентрироваться самые различные средства выдвижения: аграмматический синтаксис, лексические преобразования, риторические фигуры и т.д. Метафоры, помещенные в эмпирическую часть, могут привлекать большее внимание, чем формулировка самого обобщения. Зачастую, однако, такие «яркие моменты» эмпирической части непосредственнее всего содержательно связываются именно с моментом постижения, который является движущей силой всего стихотворения.

21 Ibidem, s. 7.

22 Ibidem, s. 21. 


\section{2. Композиционная роль видо-временных категорий в стихотворении Бориса Пастернака «Чудо»}

Наш анализ будет состоять из двух частей. В первой части мы попытаемся показать, как категории вида и времени участвуют в выдвижении философского обобщения на фоне нарратива, а во второй - как в нарративной составляющей выносятся на первый план именно те смыслы, которые напрямую соотносятся с главным замыслом текста.

\section{1 Соотнесение эмпирической части и обобщения по принципу контраста}

Чудо анализируется значительно реже, чем другие, стихотворения Юрия Живаго (например Гамлет», Гефсиманский сад или Магдалина). Однако именно в Чуде проявляет себя один из главных мотивов цикла. История испепеления Христом смоковницы становится для Пастернака источником рефлексии о роли сверхъестественного в естественном устройстве мира. В первой части стихотворения, т.е. в пересказе евангельской истории, описывается, как природа «уподобляет себя» Христу, следуя его настроению и как бы воспроизводя его действия на каждом его шагу. В концовке автор непосредственно высказывает свою центральную мысль о подчиненности природы чуду, т.е. Богу.

Он шел из Вифании в Ерусалим,

Заранее грустью предиувтвий томим.

Колючий кустарник на круче был выжжен,

Над хижиной ближней не двигался дым,

Был воздух горяч и камым неподвижен,

И Мертвого моря покой недвижим.

И в горечи, спорившей с горечвю моря,

Он шел с небольшою толпой облаков

По пьльной дороге на чъе-то подворье,

Шел в город на сборище учеников.

И так углубился Он в мъцсли свои,

Что поле в унынъе запахло полынъю.

Все стихло. Один Он стоял посредине,

А местность лежала пластом в забытьи.

Все перемешалось: теплынь и пустыня,

И ящериць, и ключи, и ручви. 
Смоковнича высилась невдалеке,

Совсем без плодов, только ветки да листья.

И Он ей сказал: «Для какой ты корысти?

Какая мне радость в твоем столбняке?

Я жажду и алиу, а тъь-пусточвет,

И встреча с тобой безотрадней гранита.

О, как ты обидна и недаровита!

Останься такой до скончания лет».

По дереву дрожь осужденья прошла,

Как молнии искра по громоотводу.

Смоковнииу испепелило до тла.

Найдись в это времл минута свободь

У листьев, ветвей, и корней, и ствола,

Успели бвмешаться законы природъ.

Но чудо есть иудо, и иудо есть Бог.

Когда мы в смятеньи, тогда средъ разброда

Оно настигает мгновенно, врасплох. ${ }^{23}$

Ставший основой эмпирической части стихотворения сюжет в Евангелии от Матфея выглядит так: «По утру же, возвращаясь в город, взалкал. И, увидев при дороге одну смоковнии, подошел к ней и, ничего не найдя на ней, кроме листьев, говорит ей: да не будет же впредъ от тебя плода вовек. И смоковнииа тотчас засохла $»^{24}$. Пастернак свой пересказ данной истории также дает в прошедшем времени. При этом, подобно тому, как это обстоит в евангельском фрагменте, на протяжении всего пересказа его главный герой ни разу не называется по имени, а лишь местоимением он. На то, кем является он, намекается только посредством встраивания в контекст происходящего географических названий и известных фактов из жизни Христа. Отметим также, что в стихотворении у данной истории нет не только названного по имени героя, но и четко обозначенного начала. Первыми строками открывается картина, когда он уже находится в пути. Такие приемы позволяют подчеркнуть общеизвестность пересказываемой истории: нет нужды ни называть героя, ни говорить о том, как все началось, ибо - это всем знакомо. При этом повествование ведется с метаисторической позиции всезнающего наблюдателя. Лирическое «я» почти себя не обнаруживает, благодаря чему центральной фигурой остается он-Христос.

Возникает вопрос, ради чего же пересказывается данная история. Ответ на него можно отчасти найти, обращаясь к устной нарративной традиции. Соглас-

23 PASTERnAK, B. L.: Doktor Zhivago. Moskva: Azbukovnik, 2013, s. 509.

24 Евангелие от Матфея, глава 21, 18-19 In: BIBLIJA. SINODAL'NYJ PEREVOD [электронный ресурс] http://days.pravoslavie.ru/Bible/Z_mf_21_1_11 21_15_17.htm (дата доступа: 13.09.2018). 
но Флейшман ${ }^{25}$, когда в средние века пересказывались различные истории, их самая салиентная информация вовсе не состояла из последовательности и так всем известных событий. Развлекательная ценность рассказа обуславливалась появлением новых деталей, которые рассказчик выстраивал для привлечения внимания публики. Похожий прием применяется Пастернаком в Чуде. В стихотворении в библейскую историю вводятся неожиданные подробности: камыщ, пьльная дорога, поле полыни, ручъи и ключи. Оказывается, что все происходящее помещается в родной поэту русский пейзаж, и перед нами открывается новая перспектива, возникают новые ассоциации. Однако главное смысловое открытие пересказа, главная «новая деталь» все еще впереди. Она обнаруживается в последней строфе, где поэтом представляется не имеющее «аналога» в Евангелии обобщение. Ни у Матфея, умалчивающего о смысле истории, ни у Марка, у которого Иисус меняет тему разговора, видя взволнованность учеников, - нигде в Новом Завете не дается толкование истории об испепелении, и по сегодняшний день она остается одной из самых загадочных в жизни Христа. В Чуде Пастернак восполняет этот пробел в конце текста комментарием:

Но чудо есть иудо, и иудо есть Бог.

Когда мы в смятеньи, тогда средь разброда

Оно настигает мгновенно, врасплох.

Перенос фокуса с библейского сюжета на философское обобщение, т.е. переход от индивидуальной ситуации к универсальной истине выделен дискурсивно сменой прошедшего на настоящее время. Как указывает Р. Э. Лонгакер ${ }^{26}$, подобное переключение между видо-временными категориями чаще всего происходит именно в кульминационные моменты дискурса, которым присуща самая высокая напряженность. При этом в некоторых историях можно выделить не только «сюжетный пик» (англ. action peak), но и «дидактический пик» (англ. didactic peak), являющийся комментарием к представленному до или после сюжетному пику. В Чуде Пастернака сюжетным пиком в нарративной части является проклятие Христом смоковницы, а дидактическим пиком целого стихотворения - именно маркированный сменой темпоральной категории лирический комментарий к этому событию. В последней строфе уже не идет речь о прошлом опыте, а наступает вербализация универсальной мысли, которая является актуальной в любое время восприятия лирического высказывания.

Сдвиг на уровне темпоральной структуры текста совпадает с появлением в лирическом высказывании местоимения мы. До этого главным человеческим субъектом, привлекающим внимание читателя, был он, Христос. Мы акцентирует теперь внимание на присутствии автора, чей голос раныше растворялся в безлично-нарративном повествовании. Это сочетание самообнаружения лирического

25 FLEISCHMAN, Suzanne: Tense... Op. cit., s. 173.

26 LONGACRE, Robert E.: The Grammar... Op. cit., s. 37. 
«я» в инклюзивном мы с переходом на настоящее время, которое способствует сокращению дистанции между читателем и событием ${ }^{27}$, позволяет достичь в Чуде стилистического әффекта, названного в работе В. И. Тюпы «перформативной суггестией»:

«Перформативная суггестия представляет собой вовлечение адресата в актуальное коммуникативное событие, тогда как нарраиия дистаниирует адресата не только от повествуемого события, но и от фигуры повествователя: оставаясь участником «события рассказывания», слушатель не может совмещать себя с рассказчиком, а с лирическим героем - может и даже призван к этому: „Я нахожу себя в эмочионально-взволнованном чужом голосе, воплощаю себя в чужой воспеваюший голос, нахожу в нём авторитетный подход к своему собственному внутреннему волнению"» ${ }^{28}$.

Получается, что, выдвигая философское обобщение на фоне «эмпирических обстоятельств», переключение с прошедшего на настоящее время маркирует переход от известного к новому, а также переход от нарративной к чисто лирической, «перформативной» части, в которой читатель уже не дистанцируется от нарратора, а может отождествлять себя с ним.

\section{2 Композиционная роль видо-временных категорий в оформлении «растянутого выдвижения»}

В современной лингвопоэтике концепция дискурсивного выдвижения самую широкую разработку получила в исследованиях Дж. Лича ${ }^{29}$, считавшего, что привлечение внимания читателя к определенным элементам сообщения всегда связано с некоторым отклонением от нормы. Норму, в зависимости от контекста и точки зрения, могут составлять, например, общепринятые правила, описываемые в грамматиках данного языка, или установленные обществом правила речевого поведения. Дж. Лич выделяет также выдвижение через «конвенциональную девиацию», т.е. отклонение от нормы, свойственной данной художественной конвенции, например литературному жанру. Девиация иного типа внутритекстовая - происходит, если автор отклоняется от того, что установлено как норма для данного стихотворения, например, неожиданно сменяя метрику стиха. Несложно заметить, что в своей теории Дж. Лич ориентируется на идеи В. Шкловского и русских формалистов, развивавшиеся позже Пражской лингвистической школой. Предложенное Я. Мукаржовским понятие актуализаиии, предусматривающее такое использование языковых средств, которое привлекает внимание само по себе и воспринимается как необычное, лишенное автоматизма, вошло в английскую традицию именно как выдвижение (англ. foregrounding). Дж. Лич в своих работах выделяет две основные формы выдвижения:

27 подробнее см. FLEISCHMAN, Suzanne: Tense... Op. cit.

28 TJUPA, V. I.: Vvedenie v sravnitel'nuju narratologiju. Moskva: Intrada, 2013, s. 119.

29 См. например, статьи Дж. Лича разных лет в сборнике LEECH, G.: Language in Literature. London - New York: Routledge, 2008. 
1) Там, где допускается выбор, поэт выходит за нормативные рамки.

2) Там, где допускается выбор, поэт отказывается выбирать различные возможности и в нескольких последовательных позициях пользуется одним и тем же вариантом.

Для нас одним из важнейших понятий, которыми оперирует Дж. Лич, является «расширенное» или «растянутое выдвижение» (англ. extended foregrounding), которое предполагает, что отдельные выдвигаемые компоненты текста связаны между собой и соотносятся с общей структурой текста. Речь здесь идет о степени регулярности, с которой определенная схема выдвижения повторяется на протяжении всего текста. При этом опознание выбранного механизма как направленного на выдвижение зависит от нашей субъективной оценки того, появляется ли данная конструкция настолько часто, что можно это считать отклонением от нормы. Пример такого растянутого выдвижения Дж. Лич усматривает в фонологии слов wind, wine, vine, veins, повторяющихся в стихотворении Дилана Томаса This bread I break.... Приведем в качестве примера вторую строфу:

Once in this time wine the summer blood

Knocked in the flesh that decked the vine,

Once in this bread

The oat was merry in the wind;

Man broke the sun, pulled the wind down.

Мы хотели бы показать, как подобная «связность» выдвижения некоторой конструкции может обеспечиваться при помощи видо-временных категорий, а также как данная конструкция иконически соотносится с главным замыслом стихотворения.

Анализируя структуру Чуда, мы используем понятие «типов предикатов», т.е. аспектуальных классов глагола, соответствующих характеру протекания и «распределения» действия во времени. Для русской аспектуальной системы очень важно противопоставление трех типов ситуаций (см., например, классическую работу Т. В. Булыгиной Семантические типы предикатов ${ }^{30}$ ):

1) состояния, т.е. явления, называемые глаголами, в значении которых обнаруживается семантический элемент стативности. Состояния отличаются гомогенностью на протяжении всего времени их существования;

2) события, предполагающие переход от одного состояния к другому. Имена событий могут употребляться в контексте глаголов со значением произошло, случилосъ. С языковой точки зрения, события не обладают длительностью;

3) процессы, т.е. длительные явления, способные занимать значительные отрезки временной оси. Особым подтипом процессов являются действия, т.е. процессы с активным субъектом, происходящие в контексте его намерений.

30 BULYGINA, T. V.: Semantičeskie tipy predikatov. Moskva: Nauka, 1982. 
Связь вида с типами предикатов проявляется в том, что «глаголь несовершенного вида могут обозначать и состояния (умирает от нетерпения, хворает, чего-то ждет), и проиессы (горит, беседует с приятелем, долго пишет писъмо), и события (внезапно понимает, каждый денъ приходит), тогда как глаголы совершенного вида используются только для обозначения собътий» ${ }^{31}$.

Нами уже отмечалось, что в стихотворении Пастернака (Живаго) у пересказываемой истории нет четко обозначенного начала. Из первого двустишья, полностью посвященного Христу (в чем можно усматривать указание, кто же будет центральной фигурой текста), мы узнаем, что он уже находится в некоем ранее начавшемся процессе, продолжая свой путь из Вифании в Иерусалим:

Он шел из Вифании в Ерусалим,

Заранее грустью предиувтвий томим.

В стихотворении нет речи о том, в каких обстоятельствах началось путешествие. Здесь назван сам процесс и указано душевное настроение главного персонажа, причем его грусть - это не отголосок прежних событий, она вызвана тем, что только еще предстоит. Христа томят предчувствия, а описываемая далее природа оказывается необычайно восприимчивой к его состоянию:

Колючий кустарник на круче был выжжен,

Над хижиной ближней не двигался дым,

Бъл воздух горяи и камъи неподвижен,

И Мертвого моря покой недвижим.

Все кругом неподвижно, словно притихшая природа боится шевельнуться, чтобы не усилить Христова горя. Те же обстоятельства, только в несколько уточненном варианте описываются и в следующей строфе:

И в горечи, споривщей с горечъю моря,

Он шел с небольшою толпой облаков

По пыльной дороге на чъе-то подворъе,

Шел в город на сборище учеников.

Все, что описывается в приводимых строках, начиная с самого появления Христа, - это процессы и состояния, выраженные посредством несовершенного вида. При этом процессное значение относится только к действию, совершаемому Христом, - трижды повторяется он шел. Природа тут вся «стативна» (кустарник был выжжен, камыш неподвижен и т.д.), а единственный приписываемый ей процесс подвергается негации и потому тоже превращается в состояние (не двигался дъмм). Тем самым Христос оказывается единственным активным участ-

31 Ibidem, s. 170. 
ником описываемой ситуации, так как процессы обычно требуют энергии для своего поддержания, а состояние - это положение дел, сохраняющееся неизменным и без притока энергии извне. Получается, что появление разных типов предикатов, но последовательно относящихся только к несовершенному виду, обеспечивает, с одной стороны, градацию активности субъектов, позволяющую отвести Христу самую динамичную роль, а с другой стороны, придает тексту некоторую сглаженность и даже монотонность.

Обратим внимание еще на одно обстоятельство: третья строфа является уточненным пересказом первой. Здесь дважды повторяется уже раньше данная информация он шел, и всякий раз только прибавляются некоторые детали. Таким повтором замедляется темп повествования, а дополнительным «замедляющим» средством становятся прошедшее время глаголов и их несовершенный вид. В первых строфах Чуда мы наблюдаем явление, похожее на то, которое на примере «Песни о Роланде» описала С. Флейшман: «движение нарративного времени замедляется наполовину в стратегических моментах (нарративные пики) при помощи секвениии двух или трех laisses, которые повторяют одну и туже информацию, снабжая ее новыми деталями» ${ }^{32}$. В случае Чуда такое «замедление камеры» является подготовкой к предстоящему «дискурсивному пику». Повторяемый процесс становится знакомым фоном, на котором в следующей - четвертой - строфе происходит первое «инициируемое» Христом событие, вызывающее последствия событийного характера также и в природе:

И так углубился Он в мысли свои,

Что поле в унынъе запахло полынъю.

Все стихло.

Вместе со сменой вида глагола, описывающего действие Христа, сменяется и вид глаголов, описывающих поведение природы: он углубился, поле запахло. Ощущаемая Христом горечь достигает высшей точки, на что непосредственно реагирует природа. Зависимость ее поведения от поведения главного персонажа подчеркивается посредством каузативной сложноподчиненной конструкции так..., что.... Именно эта конструкция оформляет взаимосвязь двух на первый взгляд независимых фактов. Зависимый характер поведения окружающего мира подтверждается и в следующих строках:

Один Он стоял посредине,

А местность лежала пластом в забытьи.

Все перемешалось: теплынь и пустыня,

И ящерицы, и ключи, и ручви.

32 FLEISCHMAN, Suzanne: Tense... Op. cit., pp. 212-213. 
Когда Христос «возвращается» кдействию процессуального характера, природа ему следует, и появляются глаголы несовершенного вида: он стоял и местность лежала. В последующем описании все перемешалосьиспользован глагол совершенного вида, но его задача - зафиксировать результат оконченного события. Представляемая ситуация ретроспективная: всё перемешалось, вероятнее всего, еще в то время, когда Христос углубился в свои мысли и когда все стихло. Теперь, когда он стоял посредине, все уже было перемешано, отчего местность лежала пластом в забытьи.

Поэт продолжает описывать поведение природы при помощи несовершенного вида:

Смоковнииа высилась невдалеке,

Совсем без плодов, только ветки да листьл.

Далее Христос, видя бесплодность смоковницы, решает ее проклясть:

И Он ей сказал: “Для какой ты корысти?

Какая мне радость в твоем столбняке?

Я жажду и алиу, а ты - пусточвет,

И встреча с тобой безотрадней гранита.

О, как ты обидна и недаровита!

Останься такой до скончания лет».

По дереву дрожь осужденъя прошла,

Как молнии искра по громоотводу.

Смоковнииу испепелило до тла.

Действие Христа обозначается совершенным видом: он ей сказал. Получается, что на грамматическом уровне смена вида опять наступает в контексте события, инициированного главным персонажем. Когда Христос завершает свое высказывание, природа в очередной раз «перенимает» особенности его поведения и происходящее в ней также приобретает моментальный характер ${ }^{33}$ : дрожь осужденъя прошла, испепелило до тла. Моментальность данных событий подтверждается сравнением как молнии искры по громоотводу, а также пояснением в следующих строках, что у дерева не было ни минуты свободы.

\footnotetext{
Найдись в это времл минута свободы

У листвев, ветвей, и корней, и ствола,

Успели б вмешаться законы природы.

Но чудо есть иудо, и иудо есть Бог.
}

33 Глаголы речи типа сказать, произнести и др., как известно, моментальны. 
Когда мы в смятеньи, тогда средь разброда

Оно настигает мгновенно, врасплох.

Подходя к анализу последней, обобщающей строфы, напомним наблюдение Сильман, что именно здесь «лирический герой как бы еще раз - в последний раз! - окидывает взором әмпирическую сторону событий, чтобы постигнуть и ощутить их суть, что и дает себл знать в известном смысловом „толчке”, сдвиге в конче стихотворения (так называемой пуанте), ${ }^{34}$.

Концовка стихотворения является своего рода итогом лирического высказывания. В грамматической структуре заключительной строфы Чуда повторяется такая же схема, какую мы наблюдали в нарративной части. Переключение с одного вида на другой происходит здесь с появлением имени Бога. Сначала в строфе следуют глаголы совершенного вида найтись, успеть, вмешаться. «Переход» на несовершенный вид - бъть, настигатъ - наступает, когда речь идет о Боге и его тождестве с чудом: Но иудо есть иудо, и иудо есть Бог...

Исследуя структуру Чуда, мы указали, что переключение с несовершенного вида на совершенный (и наоборот) всякий раз связано с появлением главного персонажа. Действия природы оформляются глаголами, выступающими в таком же виде, какой «задают» деяния Христа. Подобные смены вида иконически соотносятся с центральным замыслом текста о главенствующей над окружающим миром силе Всевышнего (воплощением которого на Земле был Христос). Получается, что регулярный повтор «аспектуальных сдвигов» на протяжении всего текста обеспечивает «растянутое», по терминологии Дж. Лича, выдвижение центрального замысла поэта.

\section{3. Итоги}

В нашем подходе мы использовали достижения нарративной теории плановости, модель плановости в лирическом тексте Т. Сильман и теорию выдвижения, предлагаемую Дж. Личем. Обращаясь к их положениям, мы не ставили целью, предложить новые интерпретации Пастернаковского Чуда. Наша цель состояла в том, чтобы обнаружить в грамматической структуре стихотворения механизмы, способствующие акцентированию тех, а не иных смыслов. И в нарративном, и в лирическом тексте можно выделить передний план и фон, и в обоих случаях важную роль в их маркировании могут играть видо-временные категории. В Чуде на фоне повествуемой в прошедшем времени нарративной части настоящее время используется с целью выдвинуть главное философское обобщение. Однако разграничение планов ни в лирике, ни в нарративе не дихотомично. Поэтому также в фоне можно найти фрагменты, лежащие ближе к переднему плану. Как мы показали на примере Чуда, в эмпирической части лирического

34 SIL'MAN, T. Ja.: Zametki... Op. cit., s. 7. 
стихотворения выделяются сильнее всего те элементы, которые особенно тесно связаны с финальным обобщением.

\section{Литература}

BULYGINA, T. V.: Semantičeskie tipy predikatov. Moskva: Nauka, 1982.

CHVANY, Catherine: Backgrounded perfectives and plot-line imperfectives: towards a Theory of Grounding in text. In: FLIER, M. S. - TIMBERLAKE, A. (eds.): The Scope of Slavic Aspect. Columbus, Ohio: Slavica, 1985, pp. 247-73.

DRY, Helen: The movement of narrative time. Journal of Literary Semantics 12, 1983, pp. 19-53.

EHRLICH, Susan: Point of View. A Linguistic Analysis of Literary Style, London: Routledge Revivals, 1990.

FLEISCHMAN, Suzanne: Tense and Narrativity: From Medieval Performance to Modern Fiction. Austin: University of Texas Press, 1990.

GIVÓN, Talmy: Beyond Foreground and Background. In: TOMLIN, Russell S. (ed.): Coherence and Grounding in Discourse. Amsterdam: Benjamins, 1987, pp. 175-88.

HOPPER, Paul: Aspect and foregrounding in discourse. In: GIVÓN, Talmy (ed.): Syntax and semantics. Discourse and syntax, vol. 12, New York: Academic Press, 1979, pp. 213-241.

HOPPER, Paul - THOMPSON, Sandra: Transitivity in grammar and discourse. Language 56, 1980, pp. 251-299.

JONES, Lary - JONES, Linda: Multiple levels of information relevance in discourse, Discourse Studies in

Mesoamerican Languages, 1: Discussion: JONES, Linda (ed.). Dallas TX: SIL and University of Texas at Arlington, 1979, pp. 3-23.

LEECH, Geoffrey: Language in Literature. London - New York: Routledge, 2008.

LICHAČEV, D. S.: Poètika hudožestvennogo vremeni. Poètika hudožestvennogo prostranstva. In: LICHAČEV,

D. S.: Poètika drevnerusskoj literatury. Moskva: Nauka, 1979, s. 209-351.

LONGACRE, Robert E.: The Grammar of Discourse. New York: Plenum, 1983.

PASTERNAK, B. L.: Doktor Zhivag. Moskva: Azbukovnik, 2013.

SHEN, Yeshayahu: Two levels of foregrounding in literary narratives. In: ZYNGIER, S. - BORTOLUSSI,

M. - CHESNOKOVA, A. - AURACHER, J. (eds.): Directions in Empirical Literary Studies: In honor of Willie van Peer, Amsterdam/Philadelphia: John Benjamins Publishing, 2008, pp. 103-111.

SIL'MAN, T. Ja.: Zametki o lirike. Leningrad: Sovetskij pisatel', 1977.

TOMLIN, R. S. 1985. "Foreground-Background Information and the Syntax of Subordination.” Text 5. pp. 85-122.

TJUPA, V. I.: Vvedenie v sravnitel'nuju narratologiju. Moskva: Intrada, 2013.

WEINRICH, Harald: Tempus. Besprochene und erzählte Welt. Stuttgart: Kohlhammer, 1971.

ZEL'DOVIČ, G. M.: Diskursivnye otnošenija v liričeskoj poèzii. Suggestivnaja funkcija. 2017 (рукопись).

\section{Электронные ресурсы}

BIBLIJA. SINODAL'NYJ PEREVOD [электронный ресурс] http://days.pravoslavie.ru/Bible /Z_ mf_21_1_11_ 21_15_17.htm (дата доступа: 13.9. 2018). 
ČECHOV, A. P.: Spat'hočetsja. [электронный ресурс] https:/ /ilibrary.ru/text/683/p.1/index.html (дата доступа 13. 9. 2018.)

\section{dr Józefina Piątkowska}

Instytut Lingwistyki Stosowanej

Uniwersytet Warszawski

ul. Dobra 55, 00-312 Warszawa, Polska

j.i.piatkowska@uw.edu.pl 
